\title{
New alternatives for wood preservation based on thermal and chemical modification of wood-a review
}

\author{
Philippe Gérardin ${ }^{1,2}$
}

Received: 15 January 2015 / Accepted: 16 November 2015 /Published online: 2 December 2015

(C) INRA and Springer-Verlag France 2015

\begin{abstract}
Key message Increasing environmental pressures appearing over the last few years have led to important changes in the field of wood protection. In this context, new technologies, based either on thermal or chemical modifications, suggest increasing interest in prospect of programmed ban of biocide products.

- Context The evolution of the regulations on the use of biocide products has led to important changes in the field of wood preservation, leading to an increasing interest for non-biocide treatments like thermal or chemical modifications to face to the programmed ban of biocide products.

- Aims The paper reviews the different non-biocide alternatives developed currently on an industrial scale, highlighting their main characteristics and applications.

- Results Different treatments have been developed on an industrial scale involving mainly thermal modifications and acetylation, furfurylation and DMDHEU constituting already available solutions.

- Conclusion Different non-biocide alternatives already exist and will become more important in the next decades due to the increasing legislative pressure driven by environmental considerations.
\end{abstract}

Handling Editor: Jean-Michel

Philippe Gérardin

Philippe.Gerardin@univ-lorraine.fr

Laboratoire d'Etudes et de Recherche sur le Matériau Bois (LERMAB) EA 4370 USC INRA, Université de Lorraine, F-54500 Vandoeuvre-les-Nancy, France

2 Faculté des Sciences et Technologies Université de Lorraine, Bld des Aiguillettes, BP 70239, F 54506 Vandoeuvre-les-Nancy cédex, France
Keywords Acetylation - Chemical modification . DMDHEU $\cdot$ Furfurylation $\cdot$ Thermo-modified wood $\cdot$ Heat treatment $\cdot$ Non-biocide treatment

\section{Introduction}

Chemical modification of wood has received a lot of attention since the middle of the 20th century. The main objectives of these modifications depend on the final use of the material. In the case of solid wood, chemical modifications are intended to improve the material's properties like its dimensional stability, mechanical properties or resistance to biodegradation, while in the case of divided wood, modifications are aimed at modifying or improving behaviour of particles or fibres for utilisation for given applications like composites, paper or new materials.

From a chemical point of view, wood is a natural composite constituted mainly of three polymers - cellulose, hemicelluloses and lignin - and to lesser extent of low molecular weight compounds called extractives. The chemical structure of these components directly influences wood's chemical reactivity. The main chemical group present in wood cell wall biopolymers is the hydroxyl group, which is in great part responsible for wood affinity for water and of its chemical reactivity. Hydroxyl groups are present as primary or secondary alcohols in cellulose, hemicelluloses and lignin, as well as phenolic groups in lignin. The aromatic structure of lignin also constitutes another possibility to perform chemical modifications of wood through reactivity of aromatic nuclei. Additionally, some other less important functional groups like carbonyl or carboxylic acid groups can be involved in wood reactivity.

Even if many investigations have been performed on wood chemical modification, only a few of them have led to practical applications. Several reasons can explain these difficulties 
in adapting academic research results to an industrial scale. One of these reasons concerns the low reactivity of wood polymers, which involves the use of highly reactive species and catalysts to allow the reactions to take place. Another reason concerns the problems of accessibility of the reactants into the wood structure, which depend on the anatomy and impregnability of each wood species. Therefore, polar solvents are often required to improve penetration of reactants in the wood cell walls, where they should react with biopolymers.

Increasing environmental pressures over the last few years have led to important changes in industrialised countries with regard to sustainable development and especially in the field of wood preservation. Conventional wood preservation systems generally involve impregnation of broadly active biocides into the wood. However, these techniques are under increasing scrutiny with respect to their environmental impacts, which may limit their applications in the future. This has led to new opportunities for the development of "nonbiocidal' alternatives based on chemical or thermal modification of wood (Schultz et al. 2007). Numerous methods have been described in the literature during the last century to modify wood. There are excellent books dealing with wood chemical modification presenting academic research performed in this area, as well as industrial applications with the development of new materials resulting from these investigations (Rowell 2005; Hill 2005). However, only a few of them have led to industrial development. The aim of this paper is to make an assessment of the main chemical modifications of wood, which currently find, or will find in the near future, opportunities for development from an industrial point of view.

\section{Chemical modifications involving the use of chemicals}

Chemical modification of solid wood is generally investigated to increase wood dimensional stability through reduction of its affinity to moisture and to improve its resistance to biodegradation. Several strategies have been described to reach these scopes. The first one concerns chemical modification of hydroxyl groups of wood cell wall polymers through esterification, carbamatation or alkylation reactions; the second one concerns impregnation of polymerisable monomers or resins into the wood structure to form after in situ polymerisation wood polymer composites.

According to the method used, the mechanism of stabilisation differs. In the case of reactions involving modification of wood hydroxyl groups, stabilisation is due to the reduction of free sites able to bind water through hydrogen bonds, but also to the bulking effect of groups grafted on wood. In the case of wood polymer composites, stabilisation is due either to the capacity of the polymer to fill the lumen reducing the accessibility to water and micro-organisms or to cross-linking of wood components.

\subsection{Acylation and acetylation treatments}

Acylation of wood has been extensively studied using a wide range of chemicals, among them, acid anhydride, acyl chloride, ketene or even carboxylic acid (Rowell 2005; Hill 2005). However, in spite of this large number of studies, only a few of them have led to industrial development. The reasons for this gap lie in the difficulties to transfer and adapt results obtained on a laboratory scale to an industrial one, due to environmental, economical and technological problems. The most promising and the most investigated acylation reaction is probably wood acetylation (Fig. 1).

Different reagents like acetic anhydride (liquid or vapour), vinyl acetate or ketene have been investigated (Rowell et al. 1986; Rowell et al. 1985; Jebrane et al. 2011). The main advantage of these reactions is to obtain modified wood free of all by-products or starting materials. Indeed, ketene allows acetylation of hydroxyl group of wood cell wall polymers without forming a by-product, while acetic acid formed during acetylation with acetic anhydride is easily removed by heating under vacuum. The reaction of wood with acetic anhydride can be carried out with or without catalyst in a range of temperatures between 100 and $130{ }^{\circ} \mathrm{C}$ followed by a vacuum step to remove unreacted anhydride and acetic acid (Rowell 2006; Minato and Ito 2004; Obataya and Minato 2009). Microwave energy is also shown to be efficient for the modification of wood by means of acetylation with acetic anhydride (Brelid and Simonson 1999; Brelid et al. 1999).

Acetylation can be performed on solid wood or on particles (flour, chips, flakes, fibres, etc.). Acetylated wood presents higher hydrophobicity and dimensional stability (Özmen 2007; Rowell 2006; Ramsden et al. 1997; Rafidah et al. 2006). Studies performed with different wood species indicated that equilibrium moisture content decreased as the degree of acetylation increased, while mechanical properties were unchanged or only slightly affected (Rowell and Banks 1987). It was found that wood species had no significant effect on dimensional stabilisation as long as similar weight gain levels were obtained. Anti-swelling efficiency values of $60 \%$ were obtained for weight percent gain of $15 \%$, while failures and cracks were observed for higher acetyl contents (Rowell et al. 1987). Acetylation also improves wood resistance to termites and micro-organisms like fungi and bacteria (Tillman 1987; Wang et al. 2002; Hill et al. 2006; Hill et al. 2009; Mohebby and Militz 2010; Gascón-Garrido et al. 2013),

$$
\text { Wood- } \mathrm{OH}+\mathrm{CH}_{3} \mathrm{COOCOCH}_{3} \longrightarrow \text { Wood-OCOCH }{ }_{3}+\mathrm{CH}_{3} \mathrm{COOH}
$$

Fig. 1 Acetylation of wood with acetic anhydride

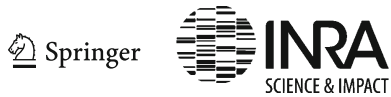


constituting an attractive alternative to classical wood preservation methods based on the use of biocides, even in contact with soil.

Acetylation is also reported to inhibit photodiscolouration and photoyellowing of wood through a reduction of the formation of coloured chromophores on the wood surface $(\mathrm{Pu}$ and Ragauskas 2005; Chang and Chang 2001). Studies performed on extracted lignin indicated that photostabilisation of acetylated lignin during light irradiation may be attributed to the acetylation of phenoxy and aliphatic hydroxyl group in lignin (Pu and Ragauskas 2005).

Acetylation has been also widely used to improve properties of wood composites. Acetylation of wood flakes prior to flakeboard manufacturing has been shown to greatly improve the dimensional stability of the finished products. Due to the reduction of the fibre saturation point and equilibrium moisture content, penetration of water soluble resins and, consequently, adhesive bonding of wood particles are very poor, leading to failure at the adhesive/wood interfaces (Mohebby et al. 2009; Rowell et al. 1987). The effect of acetylation was also examined on bending strength of finger jointed beech wood used for external joinery (Papadopoulos 2008). Results indicated that chemical modification caused a significant decrease of MOR and MOE values. Acetylation was shown to have no effect on the drying characteristics and adhesion of coating (Beckers et al. 1998). It also considerably improved their weathering performance.

Regioselectivity of reaction of acetic anhydride with wood cell wall components indicated that even if lignin is reported to react more rapidly than other wood polymers (Boonstra et al. 1996), carbohydrates were also acetylated.

There have been several attempts in the past to develop commercialisation of the wood acetylation process, but these were unsuccessful because of an unfavourable economic climate. However, because of the increasing interest in the development of renewable resources and of the restriction of use of different wood preservatives due to the application of the Biocidal Products Directive of the European Parliament adopted in 1998, new opportunities have appeared. The Titan Wood Company was formed in 2003 and started to produce acetylated wood in 2005 at Arhnen in The Netherlands using a pilot plant acetylation reactor of $2300 \mathrm{~L}$ capacity. Acetylated wood are sold under the trade name ACCOYA ${ }^{\circledR}$.

Mixed acetic-fatty esters have been also reported recently to allow modification of wood (Peydecastaing et al. 2009) (Fig. 2).

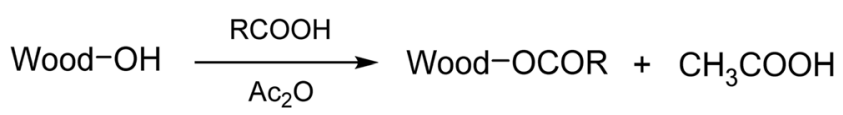

Fig. 2 Acylation of wood with mixed acetic-fatty esters
This method permits the grafting of acyl groups on wood leading to dimensionally stable treated wood bearing acetyl and fatty acid acyl chains, showing improved water repellency, which was recently unsuccessfully marketed by Lapeyre under the trade name of Wood Protect.

\subsection{DMDHEU treatment}

$\mathrm{N}$-methylol compounds, like 1,3-dimethylol-4,5dihydroxyethyleneurea (DMDHEU), are used as a wrinkleresistant finish in the textile industry. They are, therefore, expected to enhance the resistance of wood to weathering because they can cross-link the cell wall and dimensionally stabilise wood (Fig. 3).

DMDHEU was used to modify wood blocks to different weight gain reducing significantly the degradation of wood exposed to artificial weathering and preventing the degradation of the wood cell wall polymers (Xie et al. 2005). Pore size distribution determined by differential scanning calorimetry indicated that DMDHEU reduced the pore size of the samples by occupying the void space present in the cell wall (Dieste et al. 2009a). DMDHEU-modified wood appears to be more hygroscopic than unmodified wood due to the increase of $\mathrm{OH}$ groups caused by the modification with DMDHEU (Dieste et al. 2008a).

The effects of wood modification with DMDHEU on the coating performance of solvent and water-borne finishes were investigated by several authors. Xie et al. (2006) demonstrated that modification of the wood substrate with DMDHEU is compatible with both water-borne and solvent-borne finish systems and improves their wet adhesion on the wood surface. Petrič et al. (2007) investigated wettability of commercially available acrylic water-borne coatings on oil heat-treated and DMDHEU-modified Scots pine wood. Even if these treatments increased the hydrophobic character of wood, they have no negative effect on wetting of wood surfaces by water-borne coatings, which exhibited much better wetting on modified substrates than on unmodified substrates.

The gluing ability of plywood produced with DMDHEUmodified veneers was also investigated (Dieste et al. 2009b). The shear strength, the cohesive wood failure and the delamination were determined in plywood made with DMDHEUmodified veneers of beech, birch and pine using phenolic resins. Even if the samples constructed with unmodified veneers presented higher shear strengths and higher cohesive wood failures than the samples constructed with modified veneers, all shear strength values obtained met the European requirements of plywood designed for exterior conditions. The dimensional stability and mechanical properties of plywood produced with DMDHEU-modified veneers were also measured (Dieste et al. 2008b). The mechanical properties tested were Brinell hardness, modulus of elasticity in bending (MOE), bending strength (BS) and work to maximum load in 
Fig. 3 Reaction of wood with DMDHEU

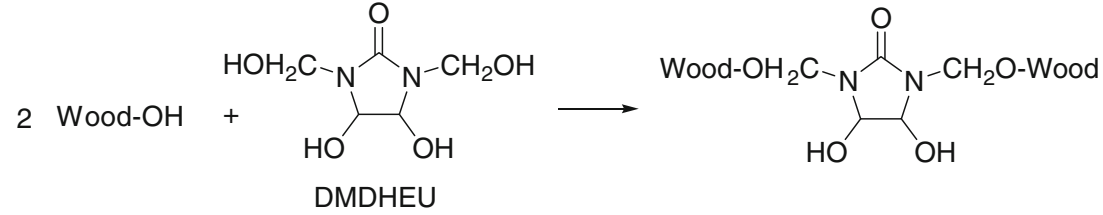

bending (WMLB). Plywood made from DMDHEU-modified samples presented higher dimensional stability, while MOE and BS were unaffected. The WMLB decreased in the modified samples and Brinell hardness increased.

The effect of treatments with DMDHEU alone or in combination with magnesium chloride as catalyst on the tensile properties of pine wood was also investigated (Xie et al. 2007). The results indicated considerable strength losses of all treated samples. The higher strength losses observed in the case of catalysed reactions were attributed to hemicelluloses degradation. Microscopic observations revealed that catalysed DMDHEU treatment changed the predominant failure mode from interfibre fracture in untreated samples to intrafibre fracture. The mechanical strength of DMDHEUtreated wood has been studied by Yuan et al. (2013) with different catalysts and different treatment temperatures. No strength loss has been observed for mild curing condition, while harder curing conditions result in a significant decrease of the mechanical strength properties.

Another recent study performed on DMDHEU-treated poplar indicates an increase of the hardness and of the compression strength perpendicular to grain, while MOR and impact strength decreased as the WPG increased (Jiang et al. 2014).

The protection mechanism of DMDHEU-treated against wood-rotting fungi was investigated by Verma et al. (2009). The decay resistance of beech- and pine-treated blocks treated increased with increasing weight percent gain (WPG) of DMDHEU, full protection being reached at WPGs of approximately $15 \%$ (beech) and $10 \%$ (pine). The same authors investigated metabolic activity of the fungi in the wood blocks (Verma et al. 2008). Fungal activity depends on the WPG and on the mass loss caused by the fungi, but is detected even in wood blocks of the highest WPG, showing that the treatment was not toxic to the fungi. It can be considered, therefore, as a 'non-biocidal' alternative to classical preservation methods involving the use of biocides.

More recently, DMDHEU-modified wood has been shown to be resistant against Mediterranean termites (GasconGarrido et al. 2013) as well as against marine borers (Lopes et al. 2014). Boric acid and phenylboronic acid have been added into aqueous solutions of DMDHEU to improve wood durability (Yalinkilic et al. 1999). DMDHEU reduced boron leachability, while boron appeared to decrease cross-linking efficacy of DMDHEU. Decay resistance against brown- and white-rot fungi increased considerably.
The Belmadur process based on DMDHEU utilisation is marketed by BASF. The treatment is realised in two stages: the first stage consists of impregnating the wood with an aqueous solution of a cross-linking agent using classical vacuumpressure impregnation plant. The second stage consists of drying the impregnated wood at a temperature of more than $100{ }^{\circ} \mathrm{C}$ causing reticulation of the DMDHEU resin.

\subsection{Furfurylation treatment}

Wood modification with furfuryl alcohol is a non-toxic alternative to conventional preservation treatments. This process, which has been known for several decades, is based on in situ polymerisation of furfuryl alcohol (Fig. 4).

Recently, the use of furfuryl alcohol obtained from renewable hydrolysed biomass waste and improvement of the polymerisation process, has led to the development of commercial production according to the Kebony technology, mainly for flooring purposes (Lande et al. 2008). The properties of furfurylated wood depend on the retention of grafted/ polymerised furfuryl alcohol in the wood. According to the modification levels, a wide variety of properties like dimensional stability, hardness, MOR, MOE, resistance to decay and insect attacks were improved (Epmeier et al. 2004; Lande et al. 2004a). Equilibrium moisture content decreases after fufurylation (Epeimer et al. 2007). Two main processes for production of furfurylated wood have been developed for Kebony ASA: KebonyTM for hardwood modification and VisorWoodTM for softwood modification. NMR investigations with soluble lignin models indicated that the furan polymer grafts to lignin, supporting observations made with wood materials (Nordstierna et al. 2008). Toxicity of furfuryl alcohol may constitute a drawback for this treatment, however, toxicity is strongly reduced after polymerisation. Ecotoxicology of furfurylated wood and leachates from furfurylated wood were reported in different studies (Lande et al. 2004b; Lande et al. 2004c; Pilgard et al. 2010a, b). Results showed no significant ecotoxicity, while combustion

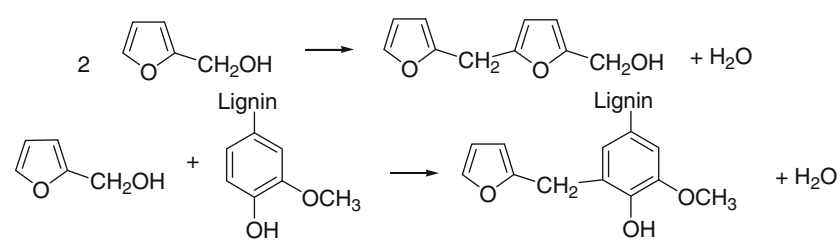

Fig. 4 Main reactions involved in polymerisation of furfuryl alcohol 
did not release any volatile organic compounds or polyaromatic hydrocarbons above normal levels for wood combustion. Similarly, Vetter and colleagues demonstrated that furfurylation is capable of protecting the wood adequately for applications under use class 3 conditions without posing a threat to the environment (Vetter et al. 2008). Furfurylation of wood is, therefore, believed to be a safe process for the environment.

Accelerated weathering tests show that furfurylation provided lower colour changes than controls after $800 \mathrm{~h}$ exposure to UV-light irradiation and water spray (Temiz et al. 2007). Surface mould growth on furfurylated, acetylated, oil heattreated and heat-treated wood substrates coated with three different coating systems exposed to outdoor conditions was also investigated (Gobakken and Westin 2008). The degree of mould growth mainly varied with time and the type of paint. Of the different modified wood substrates, furfurylated wood had the lowest degree of mould growth and acetylated had the highest. No differential patterns in susceptibility to various fungal species were detected on the surface of the different coated wood substrates.

\subsection{Other treatments based on impregnation of thermoset resins or vinylic monomers}

Thermoset resins have been used to develop some wood polymer composites with commercial applications. Compreg and Impreg treatments were developed in the 1960s in the USA. These treatments are based on the impregnation of phenolic resins into the wood structure, which after curing, greatly improves wood resistance to decay, termite and marine-borer attacks. Impreg treatment involves impregnation of phenolic resin in the wood, which was cured at a high temperature, maintaining the cell walls in a permanent swollen state (Stamm and Seborg 1962). Compreg treatment, however, involves impregnation of phenolic resin in the wood, which was cured at a high temperature under compression to reduce shrinking and swelling and to increase density and strength (Stamm and Seborg 1951). Products resulting from both of these treatments have been used for the manufacture of knife and tool handles, and musical or electrical instruments, for example, but not directly for preservation purposes.

Vinyl monomer impregnation followed by in situ polymerisation represents another promising way to enhance mechanical, dimensional and thermal stability as well as fungal and insect resistance of low natural durability wood. Different commercially available vinyl monomers, among which are acrylonitrile, glycidyl methacrylate, methyl methacrylate, hydroxyethylene methacrylate, ethylene glycol dimethacrylate, butyl acrylate, butyl methacrylate, styrene, acrylamide or acrylonitrile have been investigated (Mathias and Wright 1989; Şolpan and Güven 1998; 1999a, b, c, d; Devi et al. 2004; Zhang et al. 2006; Ajji 2006; Devi and
Maji 2007; Kumar et al. 2008; Li et al. 2010). According to the nature of the monomer used, polymerisation can take place either in the cell lumens, in the cell wall or in both (Mathias and Wright 1989; Schneider 1995; Cleland et al. 2009). Impregnation of polyglycerol methacrylate obtained from renewable agricultural by-products followed by in situ polymerisation initiated by free radical initiator, was described as an attractive alternative to conventional wood preservation procedures using broadly active biocides (Soulounganga et al. 2004). Polymerisation can be initiated by different means using either thermal free radical initiator or gamma radiation. Gamma radiation was reported by different authors to be an efficient method to initiate polymerisation (Thomas et al. 1993; Sheikh and Taromi 1993; El-Awady 1999; Ajji 2006; Gago et al. 2007). X-rays, derived from a high-energy, highcurrent electron beam can be also used to initiate in situ polymerisation of vinyl monomers. X-rays initiated polymerisation and penetrated through thick pieces of wood, where polymerisation took place allowing polymerisation of the monomers in the cell walls of wood. Having entered the cell walls and then being polymerised within the cell walls, these radiation-cured treatments increase dimensional stability of treated wood (Cleland et al. 2009).

\section{Chemical modifications using heat treatments}

Research on thermally modified wood has been the object of important investigations for several decades. Even if the effects of the heat treatment on wood durability have been known for a long time, its industrial exploitation is still recent. In the 1970s, l'École des Mines de Saint-Etienne (France) developed an industrial heat treatment process called retification leading to commercialisation of retified wood resulting from the NOW process (New Option Wood). At the same time, research undertaken in Finland led to the development of the Thermowood process. Simultaneously, other technologies were developed like the PLATO process in the Netherlands, Menz Holz OHT process in Germany (Stingl et al. 2002; Boonstra et al. 2007). In recent years, new technologies have been developed and commercialised on the market like wood heat treatment in pressurised closed conditions like WTT and IWT (Molrup) in Denmark or wood heat treatment under vacuum like Termovuoto in Italia and Timura in Germany.

Several other sites of heat treatments were set up in recent years in various European countries and in North America leading to the production and commercialisation of heattreated wood under different trade names such as Oleobois, Retiwood, BMT, and Bois Perdure. In 2012, for example, 13 production plants based on different technologies were counted in France (Abibois 2012). The industrial development of thermally modified wood was favoured by the increasing 
environmental pressure on the use of biocides leading to the progressive disappearance of different preservation products used up to now. All these technologies involves wood heat treatment at high temperatures between $180{ }^{\circ} \mathrm{C}$ and $240{ }^{\circ} \mathrm{C}$ under an oxygen free atmosphere to avoid burning involving either the use of steam, nitrogen or oil (Militz 2002). Heat treatment modifies the structure of wood cell wall polymers through different chemical reactions conferring to the material new properties. Heat-treated wood possesses new properties like improved dimensional stability and decay resistance, while its strength decreases more or less according to the treatment conditions (Tjeerdsma et al. 1998; Santos et al. 2000; Alén et al. 2002; Kamdem et al. 2002; Pétrissans et al. 2003; Gosselink et al. 2004; Hakkou et al. 2005a-c and 2006; Yildiz et al. 2005; Yildiz et al. 2006). Due to the improvement of durability towards wood-rotting fungi, heat-treated wood is considered a 'non-biocidal' alternative to classical wood preservatives for applications in hazard classes 2 and 3.

\subsection{The different industrial processes}

The main characteristics of the different heat treatment processes are described below.

\subsubsection{The Thermowood process}

Currently, Finland is the first producer of heat-treated wood with at least 10 operational production sites. An industrial scale heat treatment process, developed at VTT in cooperation with the Finnish wood product industry, produced in 2007 a little more than $80,000 \mathrm{~m}^{3}$. The ThermoWood process is licensed to the members of the Finnish Thermowood Association. This process comprises three main phases. During the first phase, wood is dried at a high temperature using heat and steam. The kiln temperature is rapidly raised to $100{ }^{\circ} \mathrm{C}$, followed by a slower temperature increase to $130{ }^{\circ} \mathrm{C}$ allowing reduction of the wood moisture content near to zero. After this, the kiln temperature is increased to temperatures between 185 and $215{ }^{\circ} \mathrm{C}$ for 2 or $3 \mathrm{~h}$. The last phase concerns cooling and moisture conditioning to bring the wood moisture content to content between 4 to $7 \%$. The atmosphere made up of overheated steam prevents cracks and induces thermohydrolysis reactions.

\subsubsection{The retification process}

Initially developed by New Option Wood (NOW), this process corresponds to a mild pyrolysis of wood under an inert atmosphere constituted of nitrogen or carbon dioxide emitted by the gas-burners used to heat the kiln. The temperature is progressively increased up to $240{ }^{\circ} \mathrm{C}$, a temperature at which retification takes place. Thermodegradation and reticulation reactions confer new properties to wood like reduced hydrophilicity, higher dimensional stability and improvement of decay resistance. The name of retification given to this process is a contraction of reticulation and torefaction.

The Perdure process is another technology currently in Quebec that is relatively close to the retification process described above. Wood is heated under an inert atmosphere in an oven using propane gas and electricity at a temperature between 200 and $230^{\circ} \mathrm{C}$. When the final temperature is attained, the temperature is maintained for a predetermined amount of time during which thermo-transformations occurred, before cooling by steam injection and conditioning.

\subsubsection{The Plato process}

The Plato process is constituted of different stages. The wood is first dried in a conventional industrial wood kiln to a moisture content of 14 to $18 \%$. After this first stage, wood is subjected to a hydro-thermolysis stage in a stainless steel reactor at temperatures between 150 and $180{ }^{\circ} \mathrm{C}$ in an aqueous environment using saturated steam as the heating medium. During this stage, hemicelluloses are strongly degraded through hydrolysis reactions, while cellulose remains intact, which is crucial to ensure final mechanical properties. The following stage concerns drying in a conventional industrial wood kiln to a moisture content of 8 to $9 \%$. Curing stage, during which thermo-reticulation occurred, is realised in a special stainless steel curing kiln at $150-190{ }^{\circ} \mathrm{C}$ under dry conditions leading to a material with moisture content near to zero. The last stage is a conditioning stage during which the moisture content of wood is elevated to a level of 4 to $6 \%$.

\subsubsection{The oil heat treatment process}

Contrary to the preceding processes, where wood is heated under nitrogen or steam to avoid combustion, oil heat treatment processes involve heating of wood in vegetable oil (sunflower, rapeseed or linseed oil). Such processes were developed in Germany by Menz Holz GMBH Company but also in France with the Oléobois process. Wood is immersed in hot oil and heated at temperatures between 180 and $220^{\circ} \mathrm{C}$ to ensure optimal durability without strength reduction.

\subsubsection{The pressurised conditions}

Commercialised by WTT and IWT companies, pressurised conditions involve higher steam pressure leading to higher relative humidity which exerts significant influence on both physical and chemical changes of wood during the treatment. Humidity softens the amorphous polymers in wood cell wall, thus increasing their flowability and reactivity at lower temperatures comparatively to other processes (Borrega and Kärenlampi 2008). 


\subsubsection{The vacuum condition}

Besides higher pressure, a partial vacuum environment has also been tried as an alternative treatment medium to limit oxygen concentration. Heat transfer under vacuum is performed either by conduction or convection. Volatile products formed during wood thermodegradation, like acetic acid, formic acid or furfural, are removed from the equipment during the treatment limiting the degradation of polysaccharides and recondensation reaction in the wood making these processes milder than others processes (Candelier et al. 2013a, b). Compared to the convection heating system, the conduction system using hot plates permits better heat transfer and limits wood deformation, treating a thin section of wood.

\subsection{Effect of heat treatment on wood cell wall polymers and wood properties}

Heat treatment modifies the structure of wood cell wall polymers conferring new properties to the material. The conditions of heat treatment directly influence the chemical decomposition of wood. Hardwoods are more susceptible to thermodegradation than softwoods. Thermal stability of the different polymers constitutive of wood differs according to their chemical structure: hemicelluloses present a lower degree of polymerisation and a higher reactivity due to their amorphous structures, which are degraded first, followed by lignin and cellulose (Hakkou et al. 2005c and 2006). The main volatile compounds are water, formic acid, acetic acid furfural resulting from degradation of hemicelluloses. Acetic acid formed during degradation of acetylated xylans catalyses depolymerisation reactions reducing the degree of polymerisation of hemicelluloses (Militz 2002). The presence of oxygen during heat treatment accelerates the degradation of wood components, considerably reducing the final properties of the material. The rate of degradation of polyoses under an oxidising atmosphere is higher than under an inert atmosphere (Kamdem and al. 1999; Yildiz and Gümüskaya 2005). ${ }^{13} \mathrm{C} \mathrm{CP}$ MAS NMR studies showed that hemicelluloses are strongly degraded after thermal treatment (Wikberg and Maunu 2004; Nguila et al. 2007). Cellulose, which presents a high degree of polymerisation and crystallinity, is generally considered as relatively resistant under heat treatment conditions used. The decomposition of lignin is observed for temperatures starting from $220^{\circ} \mathrm{C}$ with the appearance of phenolic substances such as vanillin. Modifications of wood properties after heat treatment are mainly due to the thermal degradation of hemicelluloses (Yildiz and Gümüskaya 2005; Hakkou et al. 2006; Welzbacher et al., 2007). No noticeable degradations were observed for temperatures between 80 and $180{ }^{\circ} \mathrm{C}$ under nitrogen atmosphere (Hakkou et al. 2005b), while degradations appeared at lower temperatures under steam atmosphere. According to Weiland et al. (2003), wood heat treatment at temperatures between 200 and $260{ }^{\circ} \mathrm{C}$ causes important degradations of hemicelluloses with formation of acetic acid. Two main reactions occur during acid degradation of polysaccharides and especially of hemicelluloses: rupture of the $\beta-(1-4)$ linkage between the different sugar units (arabinose, galactose, xylose and mannose) and a dehydration reaction of the resulting monomeric sugars leading to furfural or hydroxymethylfurfural, which can undergo further degradation (Fig. 5).

Degradation of amorphous cellulose, more sensitive than crystalline cellulose, starts progressively as the treatment temperature increases, leading to modification of the ratio amorphous cellulose/crystalline cellulose observed generally in the literature (Sivonen et al. 2002). Kim et al. (2001) report that the minimal temperature to break up crystalline cellulose lies between 300 and $360^{\circ} \mathrm{C}$. These same authors also report that crystalline cellulose is weakly affected for temperatures under $300{ }^{\circ} \mathrm{C}$. 5-methylfurfural and 5-hydroxymethylfurfural have been identified as cellulose degradation products of oak wood (Cutzak et al. 1999), while furfural results from degradation of pentoses present in hemicelluloses. It has been shown that dehydration products resulting from degradation of holocellulose are at the origin of the formation of carbonaceous material within the wood structure (Nguila et al. 2007).

The behaviour of extractives during thermal treatment is less obvious. Volatile extractives, like terpenes, naturally present in wood can evaporate during the first stage of thermal treatment (Mohareb et al. 2010), while new extractives resulting from thermodegradation appear starting from
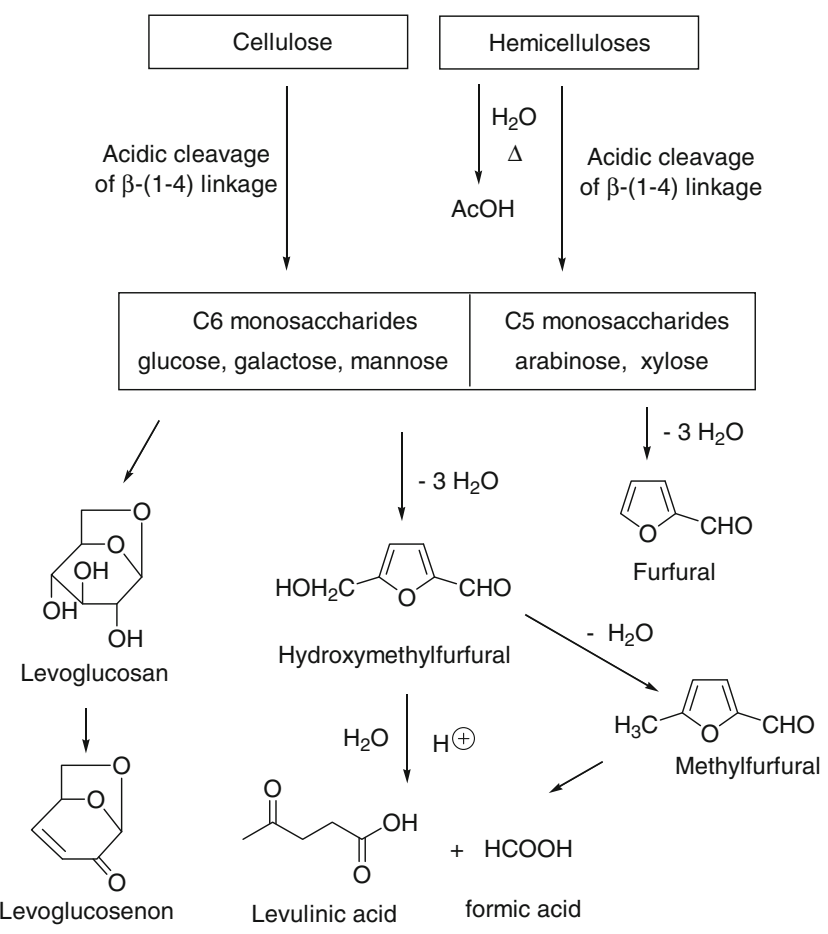

Fig. 5 Depolymerisation and degradation products of polysaccharides 
$160{ }^{\circ} \mathrm{C}$. These extractives can be subjected to further degradation reactions as the temperature and the treatment time increases, leading to the formation of by-products, which can remain in the wood or evaporate. Nuopponen et al. (2003) showed, using FTIR spectroscopy, that the heat treatment of the pine at temperatures ranging between 100 and $200{ }^{\circ} \mathrm{C}$ caused a migration of the extractives to the surface of the wood. Similar results were also recently described by Nguila Inari et al. (2011). Such a phenomenon modifies surface properties of heat-treated wood, influencing further applications like gluing or coating.

Lignin undergoes depolymerisation due to cleavage of the different $\mathrm{C}-\mathrm{O}$ bonds of $\mathrm{C} 3$ side chain and especially of $\beta-(\mathrm{O}-4)$ ether linkage (Fig. 6). At the same time, reactive intermediate species like carbonium ions, which can be formed during cleavage of benzylic $\mathrm{C}-\mathrm{O}$ bond, are involved in recondensation reactions (Weiland and Guyonnet 2003). Aldehydes like formaldehyde, ethanal, furfural or hydroxymethylfurfural are also involved in reticulation reactions with formation of methylene bridges (Tjeerdsma et al. 1998; Sivonen et al. 2002; Hakkou et al. 2006; Wikberg and Maunu 2004). These reactions would be at the origin of the dimensional stability increase observed for heat-treated wood. According to the literature, phenolic compounds formed during lignin thermodegradation have no effect on wood decay resistance of heat-treated wood (Weiland and Guyonnet 2001; Hakkou et al. 2006).

Durability of heat-treated wood increases considerably (Kamdem et al.,1999; Tjeerdsma et al. 1998). Heat-treated wood at $280{ }^{\circ} \mathrm{C}$ becomes totally resistant to decay, but its mechanical properties are strongly affected. Resistance to decay depends of the temperature and duration of treatment (Welzbacher et al. 2007; Nguila Inari et al. 2009; Šušteršic et al. 2010). Chemical modifications occurring during treatment are believed to be at the origin of durability improvement. The fact that Trametes versicolor, able to degrade lignin as well as wood polysaccharides, was unable to attack heattreated beech wood indicates that both degradation of hemicelluloses but also chemical modifications of lignin should be involved in the improvement of durability (Hakkou et al. 2006; Lekounougou et al. 2009). Heat treatment decreases the hygroscopic character and swelling of wood (Militz 2002). This behaviour has been explained by the degradation of hemicelluloses, which are the most hygroscopic polymers in wood and by thermo-reticulation reactions observed during treatment. Contact angle measurements before and after heat treatment indicate an important increase of wood hydrophobicity (Pétrissans et al. 2003). However, even if reduction of water sorption may influence decay development, no direct correlations were determined between improvement of durability and wettability changes (Hakkou et al. 2006).
Fig. 6 Depolymerisation and recondensation reactions of lignin

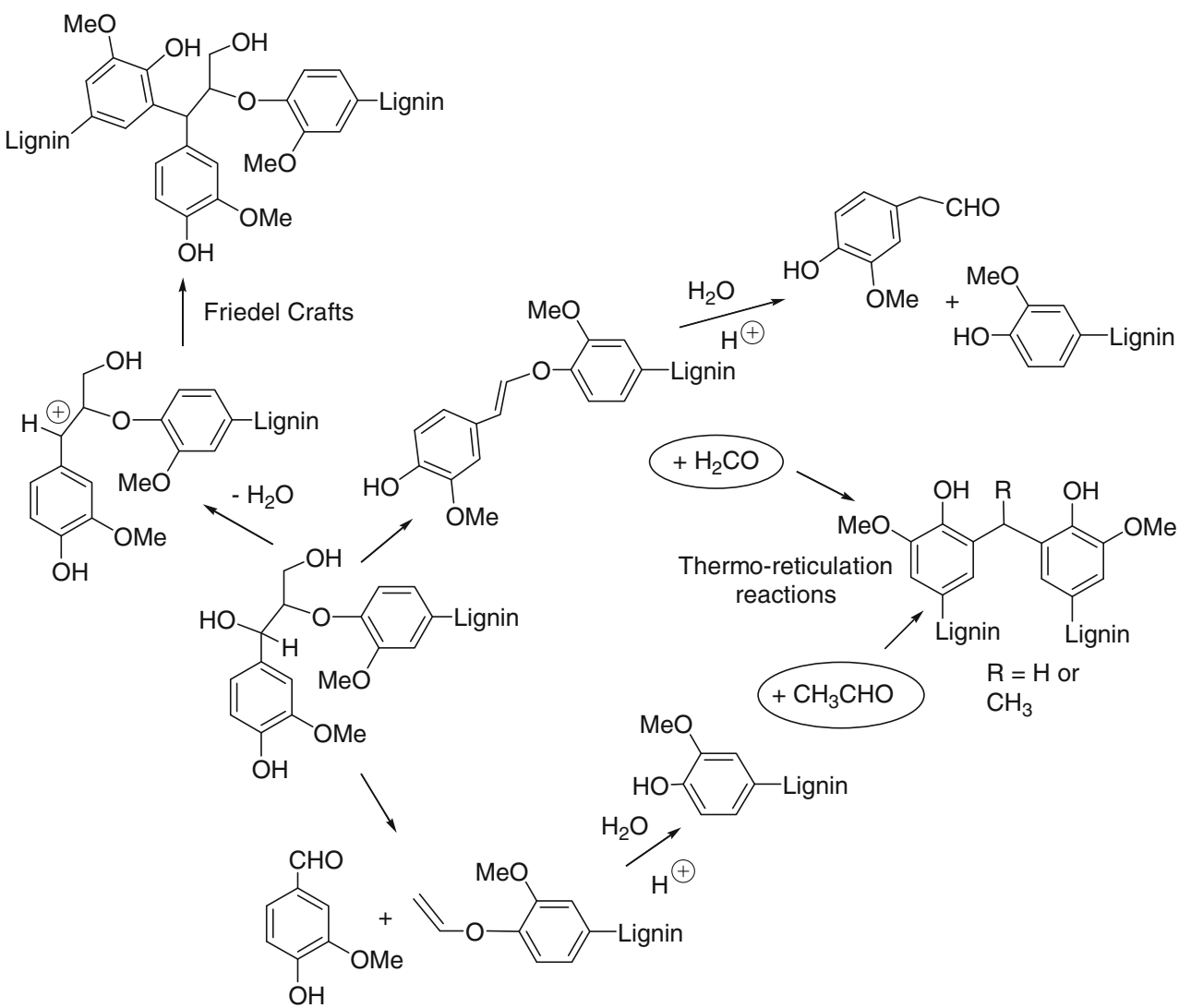




\section{Conclusions}

Modification of chemical composition of solid wood improves its properties like dimensional stability and resistance to biodegradation. Such modifications constitute attractive alternatives to classical preservation methods based on the utilisation of biocides. Among the numerous methods of chemical modifications described in the literature, only a few of them have led to developments on an industrial scale. Improvement of durability depends on the nature of the modification used. Chemical modifications performed by impregnation of different reactants into the wood structure followed by reaction of these latter ones with or without wood cell wall polymers lead to materials susceptible to be used for hazard class 3 or 4 , while chemical modifications resulting from heat treatment are compatible for hazard class 2 and 3. Even if such modified woods represent only a small part of wood used currently, their utilisation becomes more and more important and will probably continue to increase in the following years. During the past decade, wood heat treatment has been successfully developed, leading to commercialisation of heat-treated products in several European countries. The development of chemically modified wood based on impregnation of chemical was more hesitant, even if some industrial production started a few years ago. It is obvious from the evolution of wood markets during recent years in Europe that utilisation of biocide-treated wood is becoming more limited due to environmental concerns. Chemically or thermally modified wood constitutes valuable alternatives to conventional preservation methods for different applications and is going to become more important. Thermally modified woods present interesting properties for applications in class use 3 corresponding to situation in which the wood is above ground exposed to weathering, while chemically modified wood, like furfurylated or acetylated woods, present performance allowing their use up to class use 4 corresponding to situation in which the wood is in direct contact with ground or fresh water.

In all cases, the increasing legislative pressure driven by environmental considerations will support the future development of new technologies, which will become more important over the next decades. Such treatments today constitute an environmentally friendly approach to classical wood preservation based on relatively new technologies, especially for chemical modifications, which should be considered in the future as a completely new industrial processes, which can impact our environment and justify full life cycle assessment. However, controlled use of biocides will remain necessary for given applications, where thermally or chemically modified woods are not suitable or for curative treatments.

\section{References}

Abibois (2012) Traitement haute température des bois, available at http:// abibois.com/category/4-preservation-et-entretien?download $=14$

Ajji Z (2006) Preparation of pinewood/polymer/composites using gamma irradiation. Radiat Phys Chem 75:1075-1079

Alén R, Kotilainen R, Zaman A (2002) Thermochemical behaviour of Norway spruce (Picea abies) at $180-225^{\circ} \mathrm{C}$. Wood Sci Technol 36: 163-171

Beckers EPJ, De Meijer M, Mititz H, Stevens M (1998) Performance of finishes on wood that is chemically modified by acetylation. J Coatings Technol 70:59-67

Boonstra MG, Pizzi A, Tekely P, Pendlebury J (1996) Chemical modification of Norway spruce and scots pine: A 13C NMR CP-MAS study of the reactivity and reactions of polymeric wood components with acetic anhydride. Holzforschung 50:215-220

Boonstra MJ, Van Acker J, Kegel EV, Tjeerdsma BF (2007) Strength properties of thermally modified sofwoods and its relation to polymeric structural wood constituents. Ann For Sci 64:679-690

Borrega M, Kärenlampi P (2008) Effect of relative humidity on thermal degradation of Norway spruce (Picea abies) wood. J Wood Sci 54: $323-328$

Brelid PL, Simonson R (1999) Acetylation of solid wood using microwave heating: Part 2. Experiments in laboratory scale. Holz Roh Werkst 57:383-389

Brelid PL, Simonson R, Risman PO (1999) Acetylation of solid wood using microwave heating: Part 1. Studies of dielectric properties. Holz Roh Werkst 57:259-2639

Candelier K, Dumarçay S, Pétrissans A, Desharnais L, Gérardin P, Pétrissans M (2013a) Comparison of chemical composition and decay durability of heat treated wood cured at a same temperature under different inert atmospheres: nitrogen or vacuum. Polym Degrad Stab 98:677-681

Candelier K, Dumarçay S, Pétrissans A, Desharnais L, Gérardin P, Pétrissans M (2013b) Comparison of mechanical properties of heat treated beech wood cured under nitrogen or vacuum. Polym Degrad Stab 98:1762-1765

Chang ST, Chang HT (2001) Comparisons of the photostability of esterified wood. Polym Degrad Stab 71:261-266

Cleland MR, Galloway RA, Berejka AJ, Montoney D, Driscoll M, Smith L, Scott Larsen L (2009) X-ray initiated polymerization of wood impregnants. Radiat Phys Chem 78:535-538

Cutzach I, Chatonnet P, Dubourdieu D (1999) Study of the formation mechanisms of some volatile compounds during the aging of sweet fortified wines. J Agric Food Chem 47:2837-2846

Devi RR, Maji TK (2007) Effect of glycidyl methacrylate on the physical properties of wood-polymer composites. Polym Compos 28:1-5

Devi RR, Maji TK, Banerjee AN (2004) Studies on dimensional stability and thermal properties of rubber wood chemically modified with styrene and glycidyl methacrylate. J Appl Polym Sci 93:1938-1945

Dieste A, Krause A, Militz H (2008a) Modification of Fagus sylvatica (L.) with 1,3-dimethylol-4,5- dihydroxyethylene urea (DMDHEU): Part 1. Estimation of heat adsorption by the isosteric method (Hailwood-Horrobin model) and by solution calorimetry. Holzforschung 62:577-583

Dieste A, Krause A, Bollmus S, Militz H (2008b) Physical and mechanical properties of plywood produced with 1.3-dimethylol-4.5dihydroxyethyleneurea (DMDHEU)-modified veneers of Betula sp. and Fagus sylvatica. Holz Roh Werkst 66:281-287

Dieste A, Krause A, Mai C, Sèbe G, Grelier S, Militz H (2009a) Modification of Fagus sylvatica L. with 1,3-dimethylol-4,5dihydroxy ethylene urea (DMDHEU). Part 2: pore size distribution determined by differential scanning calorimetry. Holzforschung 63: 89-93 
Dieste A, Krause A, Bollmus S, Militz H (2009b) Gluing ability of plywood produced with DMDHEU-modified veneers of Fagus sp., Betula sp., and Picea sp. Int J Adhes Adhes 29:206-209

El-Awady NI (1999) Wood polymer composites using thermal and radiation techniques. J Reinf Plast Compos 18:1367-1374

Epmeier H, Westin M, Rapp A (2004) Differently modified wood: comparison of some selected properties. Scand J For Res Suppl 19:3137

Epmeier H, Johansson M, Kliger R, Westin M (2007) Material properties and their interrelation in chemically modified clear wood of Scots pine. Holzforschung 61:34-42

Gago J, López A, Santiago J, Acevedo M, Rodríguez J (2007) Woodpolymer composites obtained by gamma irradiation. AIP Conf Proc 947:481-482

Gascón-Garrido P, Oliver-Villanueva JV, Ibiza-Palacios MS, Militz H, Mai C, Adamopoulos S (2013) Resistance of wood modified with different technologies against Mediterranean termites (Reticulitermes spp.). Int Biodeterior Biodegrad 82:13-16

Gobakken LR, Westin M (2008) Surface mould growth on five modified wood substrates coated with three different coating systems when exposed outdoors. Int Biodeterior Biodegrad 62:397-402

Gosselink RJA, Krosse AMA, Van der Putten JC, Van der Kolk JC, De Klerk-Engels B, Van Dan JEG (2004) Wood preservation by lowtemperature carbonisation. Ind Crop Prod 19:3-12

Hakkou M, Pétrissans M, Gérardin P, Zoulalian A (2005a) Investigation of wood wettability changes during heat treatment on the basis of chemical analysis. Polym Degrad Stab 89:1-5

Hakkou M, Pétrissans M, Gérardin P, Zoulalian A (2005b) Wettability changes and mass loss during heat treatment of wood. Holzforschung 59:35-37

Hakkou M, Pétrissans M, Zoulalian A, Gérardin P (2005c) Investigation of wood wettability changes during Heat treatment on the basis of chemical analysis. Polym Degrad Stab 89:165

Hakkou M, Pétrissans M, Gérardin P, Zoulalian A (2006) Investigation of the reasons for fungal durability of heat-treated beech wood. Polym Degrad Stab 91:393-397

Hill C (2005) Chemical modification of wood (II): reaction with other chemicals in wood modification - chemical, thermal and other processes. John Wiley \& Sons 77-97

Hill CAS, Hale MD, Ormondroyd GA, Kwon JH, Forster SC (2006) Decay resistance of anhydride-modified Corsican pine sapwood exposed to the brown rot fungus Coniophora puteana. Holzforschung 60:625-629

Hill CAS, Curling SF, Kwon JH, Marty V (2009) Decay resistance of acetylated and hexanoylated hardwood and softwood species exposed to Coniophora puteana. Holzforschung 63:619-625

Jebrane M, Harper D, Labbé N, Sèbe G (2011) Comparative determination of the grafting distribution and viscoelastic properties of wood blocks acetylated by vinyl acetate or acetic anhydride. Carbohydr Polym 84:1314-1320

Jiang T, Gao H, Sun JP, Xie YJ, Li XR (2014) Impact of DMDHEU resin treatment on the mechanical properties of poplar. Polym Polym Compos 22:669-674

Kamdem P, Pizzi A, Guyonnet R, Jermannaud A (1999) Durability of heat-treated wood. International Research Group on Wood Preservation. Document no. IRG/WP 99-40145

Kamdem DP, Pizzi A, Jermannaud A (2002) Durability of heat-treated wood. Holz Roh Werkst 60:1-6

Kim DY, Yochiharu N, Masahisa W, Shigenori K, Takeshi O (2001) Thermal decomposition of cellulose crystallites in wood. Holzforschung 55:521-524

Kumar M, Srivastav A, Sah PL, Jaidi MGH (2008) Recent trends in low grade wood polymer composites modification techniques and their mechanical and thermal characteriztion. Advances in Heterogeneous Material Mechanics 2008: proceedings of the 2nd international conference on heterogeneous material mechanics, ICHMM 2008 p. 998

Lande S, Westin M, Schneider M (2004a) Properties of furfurylated wood. Scand J For Res Suppl 19:22-30

Lande S, Eikenes M, Westin M (2004b) Chemistry and ecotoxicology of furfurylated wood. Scand J For Res Suppl 19:14-21

Lande S, Westin M, Schneider MH (2004c) Eco-efficient wood protection: furfurylated wood as alternative to traditional wood preservation. Manag Environ Qual 15:529-540

Lande S, Westin M, Schneider M (2008) Development of modified wood products based on furan chemistry. Mol Cryst Liq Cryst 484:1/ [367]-12/[378]

Lekounougou S, Pétrissans M, Jacquot JP, Gelhaye E, Gérardin P (2009) Effect of heat treatment on extracellular enzymatic activities involved in beech wood degradation by Trametes versicolor. Wood Sci Technol 43:331-341

Li Y, Liu Y, Shi J, Li G (2010) Structure and property of PGMA/wood composite. Adv Mater Res 87-88:456-461

Lopes DB, Mai C, Militz H (2014) Marine borers resistance of chemically modified Portuguese wood. Maderas-Ciencia Y Tecnologia 16:109124

Mathias LJ, Wright JR (1989) New wood-polymer composites: impregnation and in situ polymerization of hydroxymethylacrylates. Am Chem Soc Polym Prepr Div Polym Chem 30:233-234

Militz H (2002) Thermal treatment of wood European process and their background. International Research Group on Wood Preservation. Document no. IRG/WP 02-40241.

Minato K, Ito Y (2004) Analysis of the factors influencing the acetylation rate of wood. J Wood Sci 50:519-523

Mohareb A, Sirmah P, Desharnays L, Dumarçay S, Pétrissans M, Gérardin P (2010) Effect of extractives on conferred and natural durability of Cupressus lusitanica heartwood. Ann For Sci 67:504

Mohebby B, Militz H (2010) Microbial attack of acetylated wood in field soil trials. Int Biodeterior Biodegrad 64:41-50

Mohebby B, Gorbani-Kokandeh M, Soltani M (2009) Springback in acetylated wood based composites. Constr Build Mater 23:31033106

Nguila Inari G, Mounguengui S, Dumarçay S, Pétrissans M, Gérardin P (2007) Evidence of char formation during heat treatment by pyrolysis. Polym Degrad Stab 92:997-1002

Nguila Inari G, Pétrissans M, Pétrissans A, Gérardin P (2009) Elemental composition of wood as a potential marker to evaluate heat treatment intensity. Polym Degrad Stab 94:365-368

Nguila Inari IG, Pétrissans M, Dumarcay S, Lambert J, Ehrhardt JJ, Šernek M, Gérardin P (2011) Limitation of XPS for analysis of wood species containing high amounts of lipophilic extractives. Wood Sci Technol 45:369-382

Nordstierna L, Lande S, Westin M, Karlsson O, Furó I (2008) Towards novel wood-based materials: chemical bonds between lignin-like model molecules and poly(furfuryl alcohol) studied by NMR. Holzforschung 62:709-713

Nuopponen M, Vuorinen T, Jamsa S, Viitaniemi P (2003) The effects of a heat treatment on the behaviour of extractives in softwood by FTIR spectroscopic methods. Wood Sci Technol 37:109-115

Obataya E, Minato K (2009) Potassium acetate-catalyzed acetylation of wood at low temperatures II: vapor phase acetylation at room temperature. J Wood Sci 55:23-26

Özmen N (2007) Dimensional stabilisation of fast growing forest species by acetylation. J Appl Sci 7:710-714

Papadopoulos AN (2008) The effect of acetylation on bending strength of finger jointed beech wood (Fagus sylvatica L.). Holz Roh Werkst 66:309-310

Petrič M, Knehtl B, Krause A, Militz H, Pavlič M, Pétrissans M, Rapp A, Tomažič M, Welzbacher C, Gérardin P (2007) Wettability of waterborne coatings on chemically and thermally modified pine wood. J Coat Technol Res 4:203-206 
Pétrissans M, Gérardin P, Elbakali D, Serraj M (2003) Wettability of heattreated wood. Holzforschung 57:301-307

Peydecastaing J, Vaca-Garcia C, Borredon1 E, El Kasmi S (2009) Hydrophobicity of mixed acetic-fatty wood esters, European conference on wood modification

Pilgard A, Andreas T, Albert NT, Zeeland V, Gosselink JA, Westin M (2010a) Toxic hazard and chemical analysis of leacheates from furfurylated wood. Environ Toxicol Chem 29:1918-1924

Pilgard A, De Vetter L, Van Acker J, Westin M (2010b) Toxic hazard of leachates from furfurylated wood: comparisons between two different aquatic organisms. Environ Toxicol Chem 29:1067-1071

$\mathrm{Pu}$ Y, Ragauskas AJ (2005) Structural analysis of acetylated hardwood lignins and their photoyellowing properties. Can J Chem 83:21322139

Rafidah KS, Hill CAS, Ormondroyd GA (2006) Dimensional stabilization of rubberwood (Hevea brasiliensis) with acetic or hexanoic anhydride. J Trop For Sci 18:261-268

Ramsden MJ, Blake FSR, Fey NJ (1997) The effect of acetylation on the mechanical properties, hydrophobitity and dimensional stability of Pinus sylvestris. Wood Sci Technol 31:97-104

Rowell RM (2005) Chemical modification of wood in handbook of wood chemistry and wood composites, Taylor and Francis 381-420

Rowell RM (2006) Acetylation of wood. For Prod J 56:4-12

Rowell RM, Banks WB (1987) Tensile strength and toughness of acetylated pine and lime flakes. Brit Polym J 19:479-482

Rowell RM, Wang RHS, Hyatt JA (1985) Reaction of aspen and southern pine wood flakes with gaseous ketene. p. 221. Conference paper

Rowell RM, Tillman AM, Simonson R (1986) Vapor phase acetylation of southern pine, Douglas-fir, and aspen wood flakes. J Wood Chem Technol 6:293-309

Rowell RM, Youngquist JA, Sachs IB (1987) Adhesive bonding of acetylated aspen flakes, Part 1. Surface changes, hydrophobicity, adhesive penetration and strength. Int J Adhes Adhes 7:183-188

Santos JA (2000) Mechanical behaviour of eucalyptus wood modified by heat. Wood Sci Technol 34:39-43

Schneider MH (1995) New cell wall and cell lumen wood polymer composites. Wood Sci Technol 29:121-127

Schultz TP, Nicholas DD, Preston AF (2007) A brief review of the past, present and future of wood preservation. Pest Manag Sci 63:784-8

Sheikh N, Taromi FA (1993) Radiation induced polymerization of vinyl monomers and their application for preparation of wood-polymer composites. Radiat Phys Chem 42:179-182

Sivonen H, Maunu SL, Sundholm F, Jamsa S, Viitaniemi P (2002) Magnetic resonance studies of thermally modified wood. Holzforschung 56:648-654

Şolpan D, Güven O (1998) Comparison of the dimensional stabilities of oak and cedar wood preserved by in situ copolymerization of allyl glycidyl ether with acrylonitrile and methyl methacrylate. Angew Makromol Chem 259:35-37

Şolpan D, Güven O (1999a) Preparation and properties of some wood/(co)polymer composites. Angew Makromol Chem 269:3035

Şolpan D, Güven O (1999b) Preservation of beech and spruce wood by allyl alcohol-based copolymers. Radiat Phys Chem 54:583-591

Şolpan D, Güven O (1999c) Modification of some mechanical properties of cedar wood by radiation induced in-situ copolymerization of allyl glycidyl ether with acrylonitrile and methyl methacrylate. Iran Polym J 8:73-81

Șolpan D, Güven O (1999d) Improvement of mechanical stability of Beechwood by radiation-induced in situ copolymerization of allyl glycidyl ether with acrylonitrile and methyl methacrylate. J Appl Polym Sci 71:1515-1523

Soulounganga P, Loubinoux B, Wozniak E, Lemor A, Gérardin P (2004) Improvement of wood properties by impregnation with polyglycerol methacrylate. Holz Roh Werkst 62:281-285
Stamm AJ, Seborg RM (1951) Resin-treated laminated, compressed wood - compreg. USDA Forest Service, Forest Product Laboratory, report no. 1381

Stamm AJ, Seborg RM (1962) Resin-treated laminated, compressed wood - impreg. USDA Forest Service, Forest Product Laboratory, report no. 1380

Stingl R, Patzelt M, Teischinger A (2002) Ein-und Rücklick. in ausgewählte Verfahren der thermischen Modifikation. In: Lignovisionen, Modifiziertes Holz Eigenschaften und Märkte. 7-99

Šušteršic Ž, Mohareb A, Chaouch M, Pétrissans M, Petrič M, Gérardin P (2010) Prediction of decay resistance of heat treated wood on the basis of its elemental composition. Polym Degrad Stab 95:94-97

Temiz A, Terziev N, Eikenes M, Hafren J (2007) Effect of accelerated weathering on surface chemistry of modified wood. Appl Surf Sci 253:5355-5362

Thomas PT, Babu BRS, Neelakandan K (1993) Studies on certain woodplastic-composites prepared by gamma irradiation. B Mater Sci 16: $73-83$

Tillman AM (1987) Chemical modification of lignocellulosic materials: a comparison of processes. Chalmers Teckniska Hogskola, Doktorsavhandlingar 643:52

Tjeerdsma BF, Boonstra M, Pizzi A, Tekely P, Militz H (1998) Characterisation of the thermally modified wood: molecular reasons for wood performance improvement. Holz Roh Werkst 56:149-153

Verma P, Dyckmans J, Militz H, Mai C (2008) Determination of fungal activity in modified wood by means of micro-calorimetry and determination of total esterase activity. Appl Microbiol Biotechnol 80: $125-133$

Verma P, Junga U, Militz H, Mai C (2009) Protection mechanisms of DMDHEU treated wood against white and brown rot fungi. Holzforschung 63:371-378

Vetter LD, Depraetere G, Janssen C, Stevens M, Acker JV (2008) Methodology to assess both the efficacy and ecotoxicology of preservative-treated and modified wood. Ann For Sci 65:504p1$504 \mathrm{p} 10$

Wang CL, Lin TS, Li MH (2002) Decay and termites resistance of planted tree sapwood modified by acetylation. Taiwan J For Sci 17:483-490

Weiland JJ, Guyonnet R (2001) Physicochemical study of thermal treatment of wood. Récents Progrès en Génies des Procédés $15: 195-202$

Weiland JJ, Guyonnet R (2003) Study of chemical modifications and fungi degradations of thermally modified wood using DRIFT spectroscopy. Holz Roh Werkst 61:216-220

Welzbacher CR, Brischke C, Rapp AO (2007) Influence of treatment temperature and duration on selected biological, mechanical, physical and optical properties of thermally modified timber. Wood Mater Sci Eng 2007:66-76

Wikberg H, Maunu SL (2004) Characterization of thermally modified hard and softwoods by CP/MAS ${ }^{13}$ NMR. Carbohydr Polym 58 : 461-6

Xie Y, Krause A, Mai C, Militz H, Richter K, Urban K, Evans PD (2005) Weathering of wood modified with the N-methylol compound 1,3dimethylol-4,5-dihydroxyethyleneurea. Polym Degrad Stab 89: 189-199

Xie Y, Krause A, Militz H, Mai C (2006) Coating performance of finishes on wood modified with an N-methylol compound. Prog Org Coat 57:291-300

Xie Y, Krause A, Militz H, Turkulin H, Richter K, Mai C (2007) Effect of treatments with 1,3-dimethylol-4,5-dihydroxy-ethyleneurea (DMDHEU) on the tensile properties of wood. Holzforschung 61: $43-50$

Yalinkilic MK, Gezer ED, Takahashi M, Demirci Z, Ilhan R, Imamura Y (1999) Boron addition to non- or low-formaldehyde cross-linking 
reagents to enhance biological resistance and dimensional stability of wood. Holz Roh Werkst 57:351-357

Yildiz S, Gümüskaya E (2005) The effects of thermal modification on crystalline structure of cellulose in soft and hardwood. Build Environ 42:62-67

Yildiz UC, Yildiz S, Gezer ED (2005) Mechanical and chemical behavior of beech wood modified by heat. Wood Fiber Sci 37:456-461
Yildiz S, Gezer ED, Yildiz U (2006) Mechanical and chemical behavior of spruce wood modified by heat. Build Environ 41:1762-1766

Yuan J, Hu YC, Li LF, Cheng FC (2013) The mechanical strength change of wood modified with DMDHEU. Bioresources 8:1076-1088

Zhang Y, Zhang SY, Yang DQ, Wan H (2006) Dimensional stability of wood-polymer composites. J Appl Polym Sci 102:5085-5094 